\section{JURNAL ABDIMAS

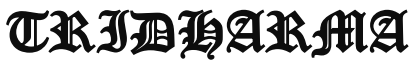

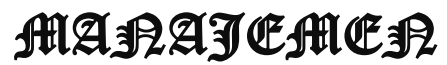

P-ISSN 2615-6849, E-ISSN 2716-070X

Jurnal ABDIMAS Vol. 2,No.3, Agustus 2021, Hal (1-9)

@ Prodi Manajemen Fakultas Ekonomi Universitas Pamulang

Email: abdimasjurnal.unpam@gmail.com Telp: (021) 741-2566

\title{
TIME MANAGEMENT FOR MILLENIAL IN PANDEMIC ERA
}

\author{
Krisnaldy, M.Khadafi Ruslam,Andikah Putra Lesmana, \\ Fery Khaeru Rizky,Alif Aria Putera,Johario Bahar Rahmaditomo
}

\begin{abstract}
Dosen Dan Mahasasiswa Prodi Manajemen
Fakultas Ekonomi Universitas Pamulang

Email : dosen01890@unpam.ac.id,Dafibeckham15@gmail.com, andikalesmanah1@ gmail.com,

Ferykhaeru@gmail.com, ariaputeraa@gmail.com,.Johario1412@ gmail.com
\end{abstract}

\begin{abstract}
ABSTRAK
Tujuan dari kegiatan Pengabdian Kepada Masyarakat ini adalah untuk melaksanakan salah satu Tri Dharma Perguruan Tinggi. Selain itu, melalui kegiatan Pengabdian Kepada Masyarakat ini, keberadaan perguruan tinggi diharapkan dapat memberikan kontribusi besar kepada pengembangan dan penerapan keilmuan dalam masyarakat.

Metode kegiatan yang digunakan adalah tim pelaksana mengunjungi Yayasan pondok pesantren dan panti asuhan nurul ikhsan yang beralamat di KP.MOMONGGOR RT/01/01 DESA KERANGGAN KEC.SETU KABUPATEN TANGERANG SELATAN, Kranggan, Kec. Setu, Kota Tangerang Selatan, Banten 15312 dan memberikan pengabdian kepada masyarakat mulai tanggal 21Maret 2021. Pelatihan ini bertujuan agar siswa dan siswi mengunjungi Yayasan pondok pesantren dan panti asuhan nurul ikhsan yang masih berusia remaja memahami pentingnya time management atau manajemen waktu untuk meraih tujuan-tujuan yang lebih besar dan bisa menerapkan perencanaan waktu tersebut dalam kehidupannya mulai sekarang, terutama sebagai bekal dalam menghadapi kesulitan ekonomi seperti di masa pandemi saat ini.

Hasil kegiatan Pengabdian Kepada Masyarakat ini adalah bertambahnya keilmuan dan keterampilan siswa-siswi Yayasan pondok pesantren dan panti asuhan nurul ikhsan, khususnya di bidang manajemen yaitu perencanaan keuangan yang akan menjadi bekal mereka dalam mengelola waktu, baik di masa normal maupun di masa kesulitan ekonomi seperti sekarang .

Ilmu yang didapatkan pada kegiatan Pengabdian Kepada Masyarakat ini diharapkan mampu memberikan semangat dalam menyampaikan pengetahuan dan memberikan motivasi serta berkontribusi bagi generasi muda, baik di lingkungan sekolah, kampus maupun masyarakat.
\end{abstract}

\section{Kata Kunci : Manajemen Waktu, Covid -19}

\begin{abstract}
The purpose of this Community Service activity is to implement one of the Tri Dharma of Higher Education. In addition, through this Community Service activity, the existence of universities is expected to make a major contribution to the development and application of science in society.

The method of activity used was the implementing team visited the Pondok Pesantren Foundation and the Nurul Ikhsan Orphanage, which is located at KP. MOmongGOR RT/01/01 KERANGGAN VILLAGE, SETU REGENCY, TANGERANG SELATAN, Kranggan, Kec. Setu, South Tangerang City, Banten 15312 and provides community service starting on March 21, 2021. This training aims to make students visit the Islamic Boarding School Foundation and Nurul Ikhsan orphanage who are
\end{abstract}




\section{JURNAL ABDIMAS

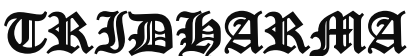

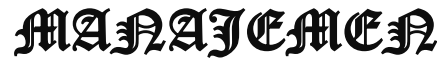

P-ISSN 2615-6849, E-ISSN 2716-070X

Jurnal ABDIMAS Vol. 2,No.3, Agustus 2021, Hal (1-9)

@ Prodi Manajemen Fakultas Ekonomi Universitas Pamulang

Email: abdimasjurnal.unpam@ gmail.com Telp: (021) 741-2566

still teenagers to understand the importance of time management or time management to achieve goals who are bigger and can apply that time planning in their lives from now on, especially as a provision to face economic difficulties such as during the current pandemic.

The result of this Community Service activity is an increase in the knowledge and skills of the students of the Nurul Ikhsan Islamic Boarding School Foundation and Orphanage, especially in the field of management, namely financial planning which will be their provision in managing time, both in normal times and in times of economic difficulties like now. .

The knowledge gained in this Community Service activity is expected to be able to provide enthusiasm in conveying knowledge and provide motivation and contribute to the younger generation, both in schools, campuses and the community.

\section{Keywords: Time Management, Covid -19}

\section{PENDAHULUAN}

Waktu adalah sesuatu hal yang tidak bisa digantikan dan dikembalikan. Menurut Ozel, Hasgul \& Duzcu (2018, p. 42) waktu merupakan sumber yang paling penting bagi seseorang dan jika dipergunakan dengan maksimal akan mendatangkan kesuksesan dan kebahagiaan. Oleh sebab itu manajemen waktu pada mahasiswa keperawatan untuk jenjang sarjana sangat esensial terutama proses belajar selama pandemi covid 19. Mahasneh, Al-Zoubi, Batayeneh, AlSawalmeh \& Mahasneh (2013, p.397) menyatakan bahwa mahasiswa di Jordania mempunyai keterampilan manajemen waktu yang kurang baik sehingga perguruan tinggi memerlukan peran yang lebih baik untuk Idea Nursing Journal Vol. XI No. 12020 ISSN : 2087-2879, e-ISSN : 2580 - 24457 meningkatkan efektivitas manajemen waktu mahasiswa melalui pelatihan, bimbingan akademik dan mahasiswa harus memperoleh keterampilan menginvestasikan waktu untuk meningkatkan prestasi belajar mereka serta tidak ada perbedaan yang bermakna dalam tingkat kesadaran mahasiswa berdasarkan lokasi tempat tinggal, jenis kelamin dan prestasi akademik. Abraham et al (2018) juga menguatkan bahwa mahasiswa jurusan kesehatan harus dilatih untuk mengembangkan berbagai keterampilan belajar dalam jangka panjang yang sangat penting bagi mereka untuk menyeimbangkan kehidupan pribadi dan profesional mereka di masa yang akan datang. Sementara itu, Noprianty (2019) menemukan bahwa secara keseluruhan, mahasiswa keperawatan yang menerapkan metode PBL (Problem Based Learning) yang aktif pada angkatan 2014 dan 2015 menunjukkan manajemen waktu yang baik yaitu $53,3 \%$. Instrumen yang berupa Kuesioner Manajemen Waktu yang dikembangkan dari Briton \& Tesser (1991) meliputi rencana jangka pendek $(58,6 \%)$, sikap terhadap waktu $(61,5 \%)$ dan rencana jangka panjang (50,9\%). Peneliti juga menyarankan partisipannya untuk memperbaiki manajemen waktu dengan membuat daftar kegiatan dan menentukan prioritas berdasarkan daftar kegiatan tersebut. Semenjak mewabahnya covid 19 di Indonesia, pemerintah mengumumkan untuk melakukan lockdown sebagai upaya untuk memutus rantai virus covid 19 yang dimulai pada 20 Maret 2020. Hal ini tentu berpengaruh pada proses belajar mengajar baik di tingkat dasar maupun di perguruan tinggi sehingga metode belajar beralih ke online learning atau lebih dikenal dengan sebutan dalam jaringan (daring). Mahasiswa dianjurkan belajar dari rumah dan kegiatan belajar mengajar serta konsultasi selama perkuliahan dilakukan melalui online misalnya dengan aplikasi zoom, google meet, whatsapp, dan lainnya. Perubahan sistem belajar ini tentu mempengaruhi manajemen waktu mahasiswa dimana hampir semua aktifitas dilakukan di rumah. Dalam hal ini, mahasiswa seharusnya mengatur waktu dengan baik antara belajar 


\section{JURNAL ABDIMAS

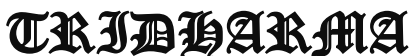

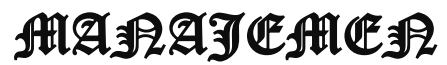

P-ISSN 2615-6849, E-ISSN 2716-070X

Jurnal ABDIMAS Vol. 2,No.3, Agustus 2021, Hal (1-9)

@ Prodi Manajemen Fakultas Ekonomi Universitas Pamulang

Email: abdimasjurnal.unpam@gmail.com Telp: (021) 741-2566 dan aktifitas lainnya di rumah. Pada kasus lain, Diab dan Elgahsh (2020) telah meneliti kesulitan yang dihadapi oleh mahasiswa keperawatan selama pandemi ini di Universitas Menoufia, Mesir. Penelitian mereka tertuju pada pengaruh hambatan yang dihadapi mahasiswa melalui sikap mereka terhadap e-learning atau pembelajaran jarak jauh selama pandemi. Hasilnya menunjukkan bahwa sikap mahasiswa terhadap e-learning yaitu negatif. Hal ini paling banyak disebabkan karena rendahnya penerapan infrastruktur dan teknologi yang mendukung. Dari penjelasan literature di atas peneliti tertarik untuk melakukan penelitian tentang kecakapan penggunaan waktu belajar pada mahasiswa keperawatan selama pandemic covid 19 di kota Banda Aceh.

\section{METODEPELAKSANAAN KEGIATAN}

Tahapan yang dilakukan dalam kegiatan ini adalah survei awal dimana kami melakukan kunjungan ke kelurahan Pondok Benda untuk membicarakan teknik pelaksanaan dan tanggal pelaksanaan serta memberitahu apa yang akan kami lakukan dan penyusunanbahan/materi kegiatan yang meliputi: slide powerpoint dan handout. Metode kegiatan yang digunakan kepada pengunjung adalah dengan memberikan penjelasan materi teori terlebih dahulu.Pelaksanaan dilakukan pada tanggal 19 s.d. 21 Oktober 2020. Peserta pada kegiatan ini adalah warga yang ada di Kelurahan Pondok Benda.

Tahapan Selanjutnya melaksanakan kegiatan ini digunakan 3 metode, yaitu: Metode Penjelasan Teori Sederhana Memberikan penjelasan singkat dan sederhana konsep ,Metode Peragaan Melakukan peragaan insitusi.
Melakukan diskusi dengan para peserta Kelurahan Pondok Benda untuk membuka wawasan agar semakin yakin bahwa kita bisa melakukan bisnis online.

\section{TUJUAN KEGIATAN}

Kegiatan pelatihan ini diharapkan mampu memberikan dampak jangka panjang bagi kehidupan siswa-siswi yang masih remaja.

a. Memberikan pengetahuan kepada siswasiswi yayasan pondok pesantren dan panti asuhab nurul ikhsan yang masih berusia remaja mengenai pentingnya perencanaan keuangan dalam mengatur dan mengelola keuangan pribadi atau keluarga untuk mencapai tujuan keuangan yang lebih besar.

b. Memberikan pengetahuan kepada siswasiswi yayasan pondok pesantren dan panti asuhab nurul ikhsan Parakan yang masih berusia remaja mengenai cara membuat perencanaan keuangan untuk pribadi maupun keluarga.

\section{HASIL DAN PEMBAHASAN}

Guru merupakan ujung tombak pendidikan di dalam proses belajar-mengajar. Guru diharapkan mampu menyiapkan peserta didik yang mampu bersaing di era globalisasi.Guru diharapkan memiliki sikap dan profesionalisme tinggi dalam mengemban tugas. Harapan penulis melalui penelitian ini dapat diketahui tingkat perilaku prokrastinasi yang dilakukan oleh guru. Temuan penelitian menunjukkan perilaku

prokrasinasi dipengaruhi oleh manajemen waktu dan efikasi-diri. Artinya, manajemen waktu

dan efikasi-diri secara bersamaan mempengaruhi perilaku prokrastinasi pada guru SMA dan

yang sederajat. Hal ini sesuai dengan teori yang mengatakan bahwa salah satu tujuan penting 


\section{JURNAL ABDIMAS

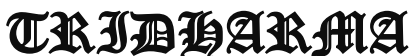

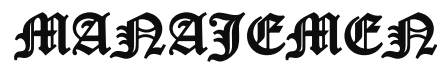

P-ISSN 2615-6849, E-ISSN 2716-070X

Jurnal ABDIMAS Vol. 2,No.3, Agustus 2021, Hal (1-9)

@ Prodi Manajemen Fakultas Ekonomi Universitas Pamulang

Email: abdimasjurnal.unpam@gmail.com Telp: (021) 741-2566 dalam penelitian prokrastinasi adalah melakukan analisis terhadap gaya kepribadian individu

yang diketahui sering menunda-nunda tugasnya (Ferrari \& Morales dalam Noor, 2012).

Dalam penelitian ini juga diketahui bahwa perilaku prokrastinasi merupakan masalah yang

lazim terjadi dan perilaku ini bisa terjadi pada siapa saja tak terkecuali guru, hal ini senada dengan penelitian yang dilakukan oleh Harriott dan Ferrari (1996) yang menyatakan $15 \%$ sampai $20 \%$ orang dewasa mengalami perilaku prokrastinasi yang kronis. Manajemen waktu dan efikasi-diri jika dihubungkan secara bersamaan memiliki hubungan yang sangat signifikan tetapi akan berbeda bila

variabel tersebut berdiri sendiri. Pada penelitian ini diketahui manajemen waktu tidak berhubungan dengan prokrastinasi. Hal ini berarti guru yang mampu mengendalikan waktunya

dengan baik belum tentu memiliki perilaku prokrastinasi yang rendah dan sebaliknya guru yang tidak mampu mengelola waktunya dengan baik belum tentu perilaku prokrastinasinya

tinggi. Hal ini sesuai hasil penelitian Gafni dan Geri (2010) yang memperlihatkan bahwa sulit untuk mengetahui perbedaan antara mahasiswa yang mengumpulkan tugas tepat waktu dengan

mahasiswa yang mengumpulkan tugas terlambat karena tidak ada hukuman yang dijatuhkan

pada mahasiswa yang terlambat mengumpulkan. Hal sebaliknya diunkapkan oleh Manktelow (2010) yang menyatakan bahwa menangguhkan sesuatu meskipun tahu urusan itu pada akhirnya tetap harus dikerjakan merupakan jebakan yang paling besar. Individu mengetahui dengan baik, namun masih saja terus

menerus terjatuh ke dalam jebakan yang membuang waktu dan energi.Hal ini dapat disimpulkan bahwa individu yang tidak mampu mengelola waktunya dengan baik sering terjebak de ngan perilaku menundanunda tugas atau pekerjaan.

Penelitian ini menguatkan pendapat pendapat sebelumnya yang menyatakan terdapat hubungan signifikan antara efikasi-diri dengan prokrastinasi. Artinya semakin tinggi efikasidiri

guru semakin berkurang perilaku prokrastinasinya dan sebaliknya semakin rendah effikasi-diri

guru, maka semakin tinggi kecenderungan untuk melakukan perilaku prokrastinasi. Penelitian Muhid yang menyatakan bahwa perilaku prokrastinasi akademik mahasiswa sangat ditentukan oleh variabel-variabel kepribadian seperti rendahnya kontrol diri, kesadaran-diri, rendahnya harga-diri, efikasidiri dan kecemasan sosial. Klaseen (2009) mengemukakan bahwa orang dewasa yang memiliki rasa percaya diri

atas kemampuannya dalam menyelesaaikan tugas-tugasnya lebih jarang melakukan perilaku

prokrastinasi. Pada masa sekarang tidaklah sulit bagi guru untuk dapat menambah pengetahuan dan wawasannya baik dalam pengembangan karir, pengelolaan pembelajaran dikelas maupun dalam peningkatan kemampuan kepribadian. Guru sudah mendapat perhatian yang besar dari pemerintah baik dalam hal kesejahteraan maupun fasilitas. Guru dapat memanfaatkan workshop atau seminar bahkan pendidikan dan pelatihan yang sering digelar di instansiinstansi

pemerintah yang ada, baik dalam naungan Kementerian Pendidikan Nasional maupun Kementerian Agama semua tergantung kemauan guru untuk berubah lebih baik mengikuti tuntutan yang ada ataukah masih ingin tetap dengan keyakinan lamanya.

\section{Fungsi - Fungsi manajemen : l) Fungsi perencanaan Pada hakekatrya perencanaan merupakan proses pengambilan keputusan yang merupakan dasar bagi}




\section{JURNAL ABDIMAS

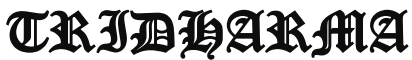 AtA}

P-ISSN 2615-6849, E-ISSN 2716-070X

Jurnal ABDIMAS Vol. 2,No.3, Agustus 2021, Hal (1-9)

@ Prodi Manajemen Fakultas Ekonomi Universitas Pamulang

Email: abdimasjurnal.unpam@gmail.com Telp: (021) 741-2566 kegiatan-kegiatan/tindakan-tindakan ekonomis dan efektif pada waktu yang akan datang. Pross ini memerlukan pemikiran tentmg apa yang perlu dikerjakan, bagaimana dan di mana suatu kegiatan perlu dilakukan serta siapa yang bertanggungjawab terhadap pelaksanaannya.

\section{2) Fungsi pengorganisasian}

Fungsi Pengorganisasian dapat didefinisikan sebagai proses menciptakan hubungan-hubungan antara fungsi-fungsi, personalia dan faktor fisik agar kegiatan-kegiatan yang harus dilaksanakan disatukan dan diarahkan pada pencapaian tujuan bersama.

\section{3)Fungsi}

pengarahan

Pengarahan merupakan fungsi manajemen yang menstimulir tindakan-tindakan agar betul-betul dilaksanakan. Oleh karena tindakantindakan itu dilakukan oleh orang, maka pengarahan meliputi pemberian perintah-perintah dan motivasi pada personalia yang melaksanakan perintah-perintah tersebut.

\section{4)Fungsi pengkoordinasi}

Suatu usaha yang terkoordinir ialah di mana kegiatan karyawan itu harmonis. terarah dan diintergrasikan menuju tujuan-tujuan bersama. Koordinasi dengan demikian sangat diperlukan dalam organisasi agar diperoleh kesatuan bertindak dalam rangka pencapaian tujuan organisasi. 5)Fungsi

pengawasan

Fungsi pengawasan pada hakekatnya mengatur apakah kegiatan sesuai dengan persyaratan-persyaratan yang ditentukan dalam rencana. Sehingga pengawasan membawa kita pada fungsi perencanaan. Makin jelas. lengkap serta terkoordinir rencanarencana makin lengkap pula pengawasan.
1. TUJUAN MANAJEMEN WAKTU Dengan pengelolaan waktu yang benar/efektif, karyawan/pimpinan akan punya waktu lebih banyak untuk mengerjakan tugas pekerjaan sesuai dengan bidang tugasnya

Tujuan manajemen waktu adalah untuk mengubah perilaku kita dari waktu ke waktu untuk mencapaia apapun tujuan umum yang telah ditetapkan, seperti meningkatkan produktifitas atau mengurangi stres. Tujuan manajemen yang lainnya adalah :

- Membuat pekerja atau karyawan bekerja menjadi lebih efektif.

- Agar tercapai ketentraman dan keseimbangan dalam hidup.

- Menyusun jadwal harian agara dapat berjalan dengan baik.

- Meletakkan prioritas tertentu sehingga kita tahu pekerjaan penting apa yang harus dikerjakan lebih dulu.

- Tercapainya tujuan suatu organisasi karena tersusunnya jadwal waktu setiap pelaksanaan kegiatan.

- Menjadikan seseorang lebih disiplin.

- Mendorong terciptanya sikap positif akan perubahan dalam diri.

- Berkurangnya penolakan terhadap perubahan.

\section{PRINSIP-PRINSIP MANAJEMEN} WAKTU

Prinsip manajemen adalah dasar-dasar atau pedoman kerja yang bersifat pokok yang tidak boleh diabaikan oleh setiap manajer/pimpinan. Dalam prakteknya harus diusahakan agar prinsip-prinsip manajemen ini hendaknya tidak kaku, melainkan harus luwes, yaitu bisa saja diubahubah sesuai dengan kebutuhan.

Prinsip-prinsip manajemen terdiri atas

1. Pembagian kerja yang berimbang Dalam membagi-bagikan tugas dan jenisnya kepada semua kerabat kerja, 


\section{JURNAL ABDIMAS

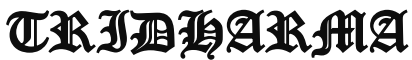

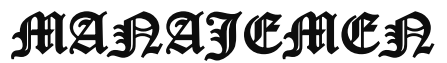

P-ISSN 2615-6849, E-ISSN 2716-070X

Jurnal ABDIMAS Vol. 2,No.3, Agustus 2021, Hal (1-9)

@ Prodi Manajemen Fakultas Ekonomi Universitas Pamulang

Email: abdimasjurnal.unpam@gmail.com Telp: (021) 741-2566 seorang manajer hendaknya bersifat adil, yaitu harus bersikap sama baik dan memberikan beban kerja yang berimbang.

2. Pemberian kewenangan dan rasa tanggung jawab yang tegas dan jelas Setiap kerabat kerja atau karyawan hendaknya diberi wewenang sepenuhnya untuk melaksanakan tugasnya dengan baik dan mempertanggung jawabkannya kepada atasan secara langsung.

3. Disiplin

Disiplin adalah kesedian untuk melakukan usaha atau kegiatan nyata (bekerja sesuai dengan jenis pekerjaan yang menjadi tugas dan tanggung jawabnya) berdasarkan rencana, peraturan dan waktu (waktu kerja) yang telah ditetapkan.

4. Kesatuan perintah Setiap karyawan atau kerabat kerja hendaknya hanya menerima satu jenis perintah dari seorang atasan langsung (mandor/kepala seksi/kepala bagian), bukan dari beberapa orang yang samasama merasa menjadi atasan para karyawan/kerabat kerja tersebut.

5. Kesatuan arah Kegiatan hendaknya mempunyai tujuan yang sama dan dipimpin oleh seorang atasan langsung serta didasarkan pada rencana kerja yang sama (satu tujuan, satu rencana, dan satu pimpinan).

Jika prinsip ini tidak dilaksanakan maka akan timbul perpecahan diantara para kerabat kerja/karyawan. Karena ada yang diberi tugas yang banyak dan ada pula yang sedikit, padahal mereka memiliki kemampuan yang sama (Dayat,n.d,pp.7-9). manajemen adalah proses pencapaian tujuan melalui kerja orang lain. Dengan demikian berarti dalam manajemen terdapat minimal 4 (empat) ciri, yaitu: 1. Ada tujuan yang hendak dicapai
2. Ada pemimpin (atasan) 3. Ada yang dipimpin (bawahan) 4. Ada kerja sama.

1. EVALUASI PENGGUNAAN WAKTU

Evaluasi merupakan tes atas tingkat penggunaan dan fungsionalitas sistem. Evaluasi dilakukan untuk memastikan kecocokan dengan permintaan pengguna/tujuan pengguna dan untuk melihat apakah hasil rancangan dengan proses uji coba sistem telah dibuat sesuai dengan penggunaan.

Tujuan adanya evaluasi :

- Melihat seberapa jauh sistem berfungsi.

- Supaya dapat mengukur kinerja dari pengguna untuk melihat keefektifan sistem dalam mendukung tugas.

Mengevaluasi penggunaan waktu berarti penilaian atau penafsiran. Evaluasi adalah proses penilaian, penilaian ini bisa menjaid netral, positif negatif atau merupakan gabungan dari keduanya. Evaluasi pemanfaatan waktu sehari untuk mengenali bagaimana cara memanfaatkan waktu dalam sehari, maka kita dapat mengevaluasi dengan bertanya kepada diri sendiri. Saat waktu dievaluasi biasanya orang yang mengevaluasi mengambil keputusan tentang nilai atau manfaatnya. Jadi, mengevaluasi waktu berarti kita mengevaluasi hal-hal yang telah dan kelak akan dilakukan.

Untuk mengenali bagaimana kita dapat mengevaluasi kegiatan dengan bertanya kepada diri sendiri, antara lain :

- Berapa banyak waktu yang digunakan untuk melakukan perencanaan ?

- Berapa banyak waktu yang dimanfaatkan untuk pekerjaan optimal ? 


\section{JURNAL ABDIMAS

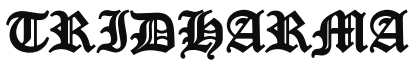

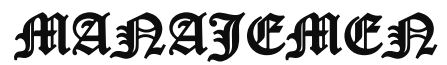

P-ISSN 2615-6849, E-ISSN 2716-070X

Jurnal ABDIMAS Vol. 2,No.3, Agustus 2021, Hal (1-9)

@ Prodi Manajemen Fakultas Ekonomi Universitas Pamulang

Email: abdimasjurnal.unpam@gmail.com Telp: (021) 741-2566
- Berapa banyak waktu untuk membaca, mengevaluasi, dan berbagi atas sesuatu pengetahuan dan pengalaman (belajar).

- Berapa banyak waktu yang dimanfaatkan untuk perjalanan menuju tempat bekerja dan pulang kembali ke rumah?

- Berapa banyak waktu untuk beristirahat, berolahraga, dan bersantai (sejenak)?

- Berapa banyak waktu yang dimanfaatkan untuk keluarga ?

Dengan melakukan evaluasi manajemen waktu, maka kita dapat mengenali bagaimana penggunaan dalm sehari sehingga dapat menemukan hal-hal mana saja yang berlebihan porsi waktunya.

- Evaluasi penerapan jadwal

- Tuliskan aktifitas tetap

- Tambahkan waktu belajar tetap

- Tambahkan waktu belajar fleksibel

- Tambahkan waktu untuk kegiatan ekstrakulikuler dan kegiatan pribadi

- Tambahkan waktu untuk rileksi

- Buat skala prioritas dari setiap kegiatan

- Perkirakan waktu yang diperlukan untuk menyelesaikan tiap kegiatan

- Apakah pengerjaannya selama ini sudah efisien ?

- Apakah kita dapat mengerjakannya dengan lebih cepat?

- Apa yang dapat kita lakukan untuk dapat mengoptimalkan aktifitas tersebut?

- Alokasikan waktu untuk setiap kegiatan

Evaluasi waktu bisa digunakan dalam sejumlah kelompok, misalnya waktu untuk keluarga, waktu untuk bekarja, dan waktu untuk pengembangan diri.

1. HAL YANG PENTING DALAM MENGELOLA WAKTU

2. Mempelajari tujuan, rencana, dan prioritas.
3. Membuat rencana kerja priodik, dapat berupa rencana harian.

4. Menentukan hal yang dapat didelegasikan pada orang lain.

5. Melakukan prioritas (yang terpenting) dan yang paling dekat batas waktunya.

6. Memberi tanda pada hal-hal yang telah selesai.

7. Memindahkan hal-hal yang belum tuntas pada rencana harian berikutnya.

8. Menyiapkan tabel kerja harian di awal atau di akhir hari sebelumnya.

9. Membuat tabel yang praktis agar mudah dibawa.

10. Tabel berisi seluruh tugas dan aktifitas yang harus diselesaikan hari itu.

11. Alokasi waktu sesuai dengan skal prioritas.

\section{KESIMPULAN DAN SARAN}

\section{Kesimpulan}

Dari kegiatan pengabdian pada masyarakat ini dapat disimpulkan bahwa:

1.Pengetahuan dan pemahaman siswa dan siswi SMK Muhammadiyah Parakan tentang pentingnya perencanaan keuangan di masa pandemi ini menjadi bertambah.

2.Semakin meningkatnya minat siswa dan siswi untuk membuat perencanaan keuangan pribadi dan menerapkannya dalam keseharian mereka.

\section{Saran}

Mengingat besarnya manfaat kegiatan pengabdian pada masyarakat ini, maka selanjutnya perlu:

1.Mengadakan sosialisasi dan pelatihan serupa pada siswa sekolah lain di Kecamatan yang lain, dengan materi yang serupa.

2.Adanya kesinambungan program pasca kegiatan pengabdian ini sehingga para siswa 


\section{JURNAL ABDIMAS

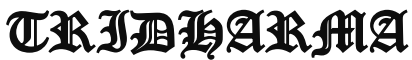

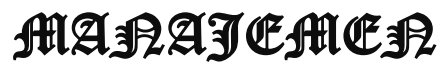

P-ISSN 2615-6849, E-ISSN 2716-070X

Jurnal ABDIMAS Vol. 2,No.3, Agustus 2021, Hal (1-9)

@ Prodi Manajemen Fakultas Ekonomi Universitas Pamulang

Email: abdimasjurnal.unpam@gmail.com Telp: (021) 741-2566 benar-benar dapat mengembangkan kemampuannya dalam membuat perencanaan keuangan

\section{DAFTAR PUSTAKA}

Elburdah, R. P., Pasaribu, V. L. D., Rahayu, S., Septiani, F., \& Metarini, R. R. A. (2021). Mompreneur Penopang Perekonomian Keluarga Di Masa Pandemi Covid-19 Dengan Bisnis Online Pada Kelurahan Pondok Benda. Abdi Laksana: Jurnal Pengabdian Kepada Masyarakat, 2(1), 75-82.

Pasaribu, V. L. D., Agrasadya, A., Shabrina, N., \& Krisnaldy, K. (2020). Menjadi Enterpreneur Muda Yang Memiliki Jiwa Leadership Untuk Menghadapi Masa Depan. Abdi Laksana: Jurnal Pengabdian

Kepada Masyarakat, 1(1).

Pasaribu, V. L. D., Susanti, F., \& Hartuti, E. T. K. (2019). Memotivasi Siswa dan Siswi SMK Letris Indonesia di Dalam Menentukan Pilihan Untuk Melanjutkan Pendidikan Atau Bekerja Setelah Lulus Sekolah. Jurnal Pengabdian Dharma Laksana, 1(2), 161-172.

Pasaribu, V. L. D., Sulaiman, S., Sutiman, S., Thaharudin, T., \& Purnomo, B. Y. (2020). Pengenalan Letak Posyandu Terdekat Dikelurahan Pisangan Dengan Manajemen Pemasaran Revolusi 4.0 Untuk Meningkatkan Pengetahuan Masyarakat Letak Dan Fungsi Posyandu Terdekat Pada Kelurahan Pisangan. Dedikasi Pkm, 1(1), 105-110.

Pasaribu, V. L. D., Oktrima, B., Prabowo, B., Arianto, N., \& Haryoko, U. B. (2020).
Progam Pendampingan Dan Penyelenggaraan Pendidikan Anak Pada Usia Dini Terhadap Prestasi Belajar Dilingkungan Rt 020 Rw 009. Kel Giri Peni. Kec Wates. Yogyakarta. Jurnal Lokabmas Kreatif, 1(1), 71-75.

Pasaribu, V. L. D., Jannah, M., Fazar, M., Putra, S. P., Monalisa, M., \& Sofa, M. (2021). MENINGKATKAN PRODUKTIVITAS USAHA DIMASA PANDEMI PADA IBU PKK RT 004/003 KELURAHAN SAWAH BARU CIPUTAT, TANGERANG SELATAN. Abdi Laksana: Jurnal Pengabdian Kepada Masyarakat, 2(2), 295-301.

Pasaribu, V. L. D., Yuniati, H. L., Pranata, R., Sembayu, R., Purba, S. M., \& Nurbayani, T. T. A. (2021). MANAJEMEN KEUANGAN UNTUK MENGHADAPI DAN BERTAHAN DI ERA COVID 19. Jurnal Abdimas Tri Dharma Manajemen, 2(2), 12-18.

Pasaribu, V. L. D., Dwiyatni, A., Sabina, C., Ridwan, M., Gunawan, D. D., \& Noviani, B. C. (2021). EVALUASI PENERAPAN 3M DIMASA PANDEMIC COVID 19. Jurnal Abdimas Tri Dharma Manajemen, 2(2), 54-60.

Pasaribu, V. L. D., Syafei, A. N., Farhan, A., Aufaizah, A., Irani, C., \& Firtiayani, S. R. (2021). PENGARUH DISPLIN PROTOKOL KESEHATAN TERHADAP PENCEGAHAN PENULARAN VIRUS COVID19. Jurnal Abdimas Tri Dharma Manajemen, 2(2), 91-98.

Priadi, A., Pasaribu, V. L. D., Virby, S., Sairin, S., \& Wardani, W. G. (2020). 


\section{JURNAL ABDIMAS

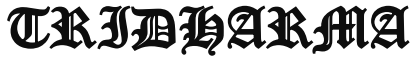

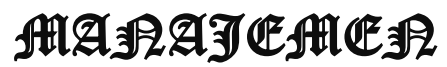

P-ISSN 2615-6849, E-ISSN 2716-070X

Jurnal ABDIMAS Vol. 2,No.3, Agustus 2021, Hal (1-9)

@ Prodi Manajemen Fakultas Ekonomi Universitas Pamulang

Email: abdimasjurnal.unpam @ gmail.com Telp: (021) 741-2566
Penguatan Ekonomi Kreatif Berbasis

Sumber Daya Desa Dikelurahan

Rempoa. Abdi Laksana: Jurnal
Pengabdian

Masyarakat, 1(3), 356-35
Kepada

\section{FOTO DUKUMEN TASI}
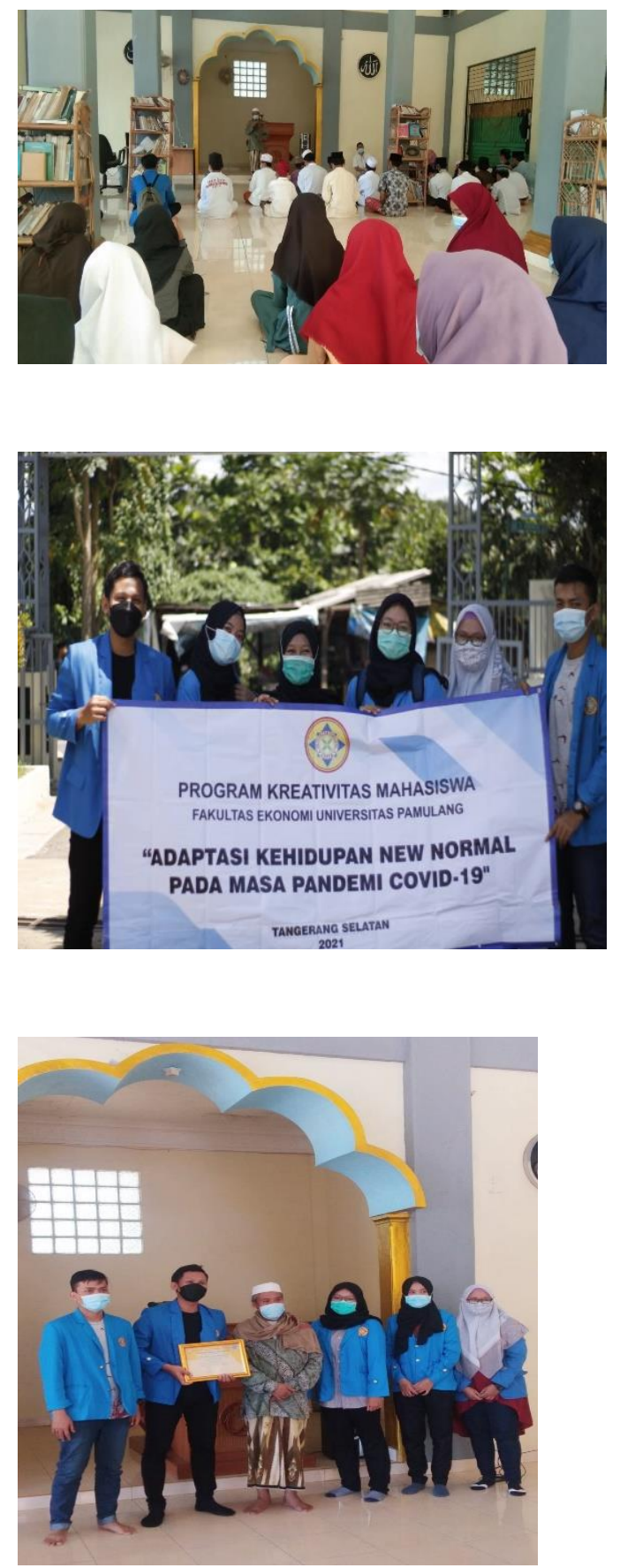